\title{
Synthesis, Characterization and Antibacterial Properties of Nickel(II) Complex with 4-Aminoantipyrine Ligand
}

\author{
Yusica Amalia Rasyda ${ }^{1}$, Mudhita Kusuma Widowati ${ }^{1}$, Soerya Dewi Marliyana ${ }^{2}$, and Sentot Budi \\ Rahardjo $^{2^{*}}$
}

${ }^{1}$ Postgraduate Program, Department of Chemistry, Faculty of Mathematics and Natural Sciences, Sebelas Maret University, Jl. Ir. Sutami 36A, Surakarta 57126, Central Java, Indonesia

${ }^{2}$ Department of Chemistry, Faculty of Mathematics and Natural Sciences, Sebelas Maret University, Jl. Ir. Sutami 36A, Surakarta 57126, Central Java, Indonesia

\section{*Corresponding author: \\ tel: $+62-81228255050$ \\ email:sentotbr@staff.uns.ac.id}

Received: June 2, 2020

Accepted: October 4, 2020

DOI: $10.22146 / \mathrm{ijc} .56552$

\begin{abstract}
The novel nickel(II) complex has been successfully synthesized through the reaction of $\mathrm{Ni}\left(\mathrm{NO}_{3}\right)_{2} \cdot 6 \mathrm{H}_{2} \mathrm{O}$ with 4-aminoantipyrine (AAP) ligand in a 1:3 mole ratio of $\mathrm{Ni}(I I)$ to AAP. The complex was characterized using UV-Vis, Atomic Absorption Spectroscopy (AAS), Infrared spectrophotometry (IR), Thermogravimetry/Differential Scanning Calorimetry (TG/DSC), conductivity, and magnetic susceptibility. The complex formula was $\left[\mathrm{Ni}(\mathrm{AAP})_{3}\right]\left(\mathrm{NO}_{3}\right)_{2} \cdot 5 \mathrm{H}_{2} \mathrm{O}$. AAP was a bidentate ligand that coordinated through the primary amine nitrogen and the carbonyl oxygen to the nickel ion. The electronic spectra of the complex displayed two peaks at $646 \mathrm{~nm}$ and $385 \mathrm{~nm}$ in accordance with the ${ }^{3} A_{2 g}(F) \rightarrow{ }^{3} T_{1 g}(F)$ and ${ }^{3} A_{2 g}(F) \rightarrow{ }^{3} T_{1 g}(P)$ transitions, respectively. This complex gave a paramagnetic property with the effective magnetic moment $\left(\mu_{\text {eff }}\right)$ of 2.96 $B M$ and the shape of an octahedron. The antibacterial test of this complex showed higher activity than the metal and its free ligand.
\end{abstract}

Keywords: nickel(II); 4-aminoantipyrine; complex; antibacterial activity

\section{- INTRODUCTION}

Antipyrine is a derivative of pyrazolone, a wellknown compound used for analgesic and antipyretic drugs. The compound has several biologically active moieties in its structure, such as $\mathrm{O}, \mathrm{N}$, and methyl groups [1-3]. Aside from biological activities, antipyrine can form stable coordination bonds with central metal ions through carbonyl groups, such as the diketone complex containing transition metals, showing antibacterial activity [4]. Other transition metal complexes from antipyrine derivatives are also reported to be useful antimicrobial agents [4]. One antipyrine derivative, in particular, the 4aminoantipyrine (AAP) has gained significant attention from medicinal chemists due to the various pharmacological activities such as antimicrobial, antiinflammatory, analgesic, and antiviral [5-8]. The cyclic structure of AAP contains two nitrogen atoms, the carbonyl, and amine groups (shown in Fig. 1), impart an<smiles>Cc1c(N)c(=O)n(-c2ccccc2)n1C</smiles>

Fig 1. Structure of 4-aminoantipyrine (AAP)

enormous influence on its biological activity. Meanwhile, the carbonyl and amine groups in AAP act as donor ligands to form various coordination assemblies [9] and chelate structures. The organic-metal chelate formation imparts major changes in the ligand's biological properties and metal ions [10], thus making the study on AAP complexes fascinating. Biologically, the active central ion of complexes with stable and nontoxic is very noteworthy, in which nickel is one of the transition metals exhibiting such features, alongside antibacterial activity [11]. 
In this present work, the new nickel complex with AAP ligand was synthesized and characterized by various spectroscopic techniques. Further, the antibacterial activity of nickel(II), AAP, and the complex was studied using the diffusion method described by Kirby Bauer [12].

\section{- EXPERIMENTAL SECTION}

\section{Materials}

All chemical substances and solvents used in the synthesis were of analytical grade and applied without purification. All chemicals such as $\mathrm{Ni}\left(\mathrm{NO}_{3}\right)_{2} \cdot 6 \mathrm{H}_{2} \mathrm{O}$, 4aminoantypirine, methanol, dimethyl sulfoxide (DMSO), nitric acid, $\mathrm{CuSO}_{4} \cdot 5 \mathrm{H}_{2} \mathrm{O}, \mathrm{FeSO}_{4} \cdot 7 \mathrm{H}_{2} \mathrm{O}, \mathrm{CuCl}_{2} \cdot 2 \mathrm{H}_{2} \mathrm{O}$, $\mathrm{CoCl}_{2} \cdot 6 \mathrm{H}_{2} \mathrm{O}, \mathrm{CrCl}_{3} \cdot 6 \mathrm{H}_{2} \mathrm{O}$, and $\mathrm{FeCl}_{3} \cdot 6 \mathrm{H}_{2} \mathrm{O}$ were procured from E. Merck.

\section{Instrumentation}

The electronic spectra of $\mathrm{Ni}\left(\mathrm{NO}_{3}\right)_{2} \cdot 6 \mathrm{H}_{2} \mathrm{O}$ and the complex in the methanol solution were analyzed on a UVVis Double Beam Lamda 25 Perkin Elmer spectrophotometer. The metal percentage in the complex sample was identified by the Atomic Absorption Spectrometer (AAS) Shimadzu AA-6650. The samples' IR spectra of $\mathrm{KBr}$ pellets were recorded on the Prestige-21 Shimadzu spectrophotometer for frequencies ranging from 400 to $4000 \mathrm{~cm}^{-1}$. Thermal analysis (TG/DSC) was performed on a Diamond STA Linseis PT-1600 with a heating rate of $80{ }^{\circ} \mathrm{C} / \mathrm{min}$. Molar conductivity was measured on a Jenway CE 4071 conductivity meter at $29^{\circ} \mathrm{C}$, while the effective magnetic moment $\left(\mu_{\text {eff }}\right)$ was read on the Auto Sherwood Scientific 10169 Magnetic Susceptibility Balance at $26{ }^{\circ} \mathrm{C}$. The diameter of the inhibition zone of the antibacterial activity test was measured using an electronic digital caliper OEM 25363 with a precision of $\pm 0.025 \mathrm{~mm}$.

\section{Procedure}

\section{Synthesis of Ni(II)-4-aminoantipyrine}

The complex was prepared by constantly stirring a $10 \mathrm{~mL}$ of the methanolic solution of AAP $(0.610 \mathrm{~g}, 3 \mathrm{mmol})$ followed by the dropwise addition of $\mathrm{Ni}\left(\mathrm{NO}_{3}\right)_{2} \cdot 6 \mathrm{H}_{2} \mathrm{O}$ $(0.291 \mathrm{~g}, 1 \mathrm{mmol})$ into $7 \mathrm{~mL}$ methanol. Thereafter, the admixture was refluxed for $3 \mathrm{~h}$, and the resulting solution was evaporated into half of the initial volume. A final dark green precipitate was obtained after three weeks. The solid was recrystallized with methanol, filtered, and dried under a vacuum desiccator (yield: $0.285 \mathrm{~g}$, $32.29 \%$ ). UV-Vis spectroscopy (in methanol, $\lambda_{\max } \mathrm{nm}$ ): 385, 729. Atomic Absorption spectroscopy (in $\mathrm{HNO}_{3}$, \%): calc., for Ni: 6.65, found: Ni, 6.63. Selected FTIR $\left(\mathrm{KBr}, \mathrm{cm}^{-1}\right): 3397 v(\mathrm{O}-\mathrm{H})_{\text {н2о }}, 3198 ; 3108 v(\mathrm{~N}-\mathrm{H}), 1616$ $v(\mathrm{C}=\mathrm{O}), 1384 \mathrm{~cm}^{-1} v(\mathrm{~N}-\mathrm{O})_{\mathrm{NO} 3}, 1353 v(\mathrm{C}-\mathrm{N}), 507 v(\mathrm{Ni}-$ $\mathrm{O}), 431 v(\mathrm{Ni}-\mathrm{N})$. Molar conductivity (in water, $\mathrm{S} \mathrm{cm}^{2}$ $\left.\mathrm{mol}^{-1}\right): 234 . \mu_{\text {eff }}(\mathrm{BM}): 2.93$.

\section{Antibacterial activity test}

The antibacterial activities of the nickel salt, AAP, and the nickel complex were evaluated against Escherichia coli ATCC 25922 (Gram-negative) and Staphylococcus aureus ATCC 25923 (Gram-positive) using the agar disc diffusion method (Kirby-Bauer). Both bacterial suspensions in $\mathrm{NaCl}$ solution were inoculated on the surface of the Mueller Hinton agar media. Varying concentrations of the tested samples were prepared in DMSO at 62.5, 125, 250, 500, and $1000(\mu \mathrm{g} / \mathrm{mL})$. Each sample $(10 \mu \mathrm{L})$ was transferred onto a $6 \mathrm{~mm}$ blank paper disc before transferring onto the agar media. For each assay, chloramphenicol and DMSO were used as the positive and negative control, respectively. The inhibition zones were observed by measuring the clear zone around the paper discs after incubation at $37{ }^{\circ} \mathrm{C}$ for $24 \mathrm{~h}$, and the results were statistically analyzed with the Duncan Multiple Range Test (DMRT).

\section{- RESULTS AND DISCUSSION}

The Ni(II) complex was synthesized in a 1:3 mole ratio of metal-ligand in methanol. AAP ligand was coordinated to nickel ion to form a $0.285 \mathrm{~g}$ dark green solid. The obtained complex was stable in air, nonhygroscopic, and completely soluble in water, methanol, ethanol, DMSO, and DMF.

\section{Formation of The Complex}

$\mathrm{Ni}(\mathrm{II})$-AAP complex formation can be indicated by the shift of UV-Vis maximum wavelength of $\mathrm{Ni}(\mathrm{II})$ solution in methanol towards the lower wavelength, which can be seen in Fig. 2. Maximum wavelength of 


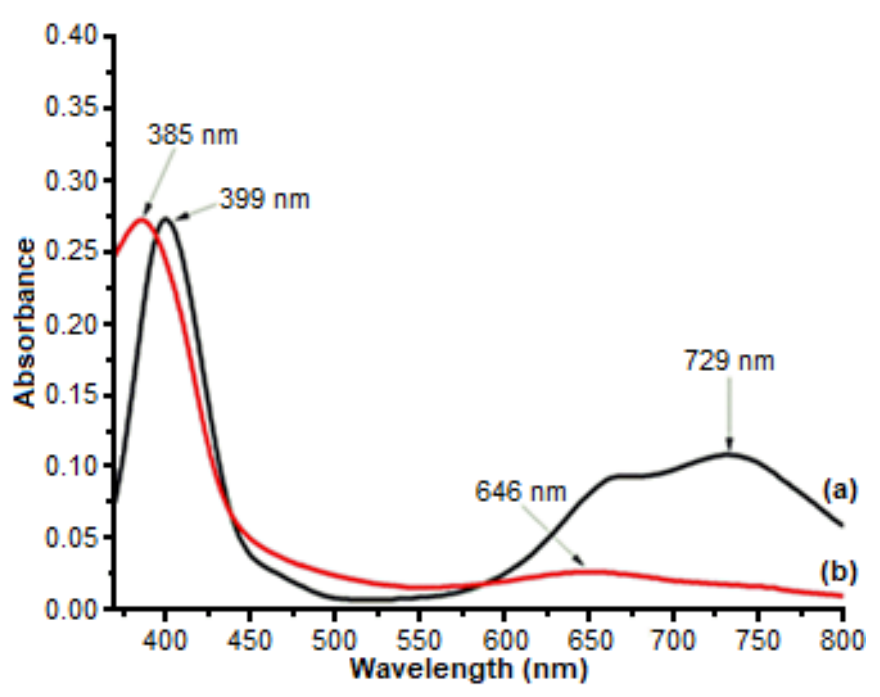

Fig 2. The electronic spectra of (a) $\mathrm{Ni}\left(\mathrm{NO}_{3}\right)_{2} \cdot 6 \mathrm{H}_{2} \mathrm{O}$ $(0.0439 \mathrm{M})$ and (b) $\mathrm{Ni}(\mathrm{II})$-AAP complex $(0.0058 \mathrm{M})$ in methanol

$\mathrm{Ni}\left(\mathrm{NO}_{3}\right)_{2} \cdot 6 \mathrm{H}_{2} \mathrm{O}$ shifted from 729 and $399 \mathrm{~nm}$ to 646 and $385 \mathrm{~nm}$, respectively in the complex. The shift showed that the AAP has stronger ligand field energy than $\mathrm{H}_{2} \mathrm{O}$, as expected from the chelate effects. Moreover, AAP can substitute the coordinated position of water molecules to nickel ion solution in methanol. Hence, the proposed formula of the complex is $\mathrm{Ni}(\mathrm{AAP})_{\mathrm{n}}\left(\mathrm{NO}_{3}\right)_{2}\left(\mathrm{H}_{2} \mathrm{O}\right)_{\mathrm{x}}$, in which the " $n$ " and " $x$ " values were based on metal content (AAS), conductance, and TG/DSC.

\section{Nickel Ion Analysis by Atomic Absorption Spectroscopy (AAS)}

The nickel content in the complex was found to be $6.63 \%$, the result was compared to calculations of nickel contents of the various possible complex formula [13], as shown in Table 1. Thus, it can be estimated that the empirical formula of the nickel complex is $\mathrm{Ni}(\mathrm{AAP})_{3}\left(\mathrm{NO}_{3}\right)_{2}\left(\mathrm{H}_{2} \mathrm{O}\right)_{\mathrm{n}}(\mathrm{n}=4,5,6)$.

\section{Thermal Analysis by TG/DSC}

TG/DSC analysis is necessary to determine the possibility of the attachment of water molecules to the central metal ion, either as lattice water or coordinated ligands. The TG and DSC curves in the thermogram of the complex (Fig. 3) shows the occurrence of endothermic reaction at $85.4{ }^{\circ} \mathrm{C}$ (DSC) in the temperature range $52.9-119.3{ }^{\circ} \mathrm{C}$, with a one-step $11.04 \%$ weight loss (TG) that was equivalent to the release of five water molecules. It was reported that the degradation stage at $30-130{ }^{\circ} \mathrm{C}$ involves the release of water molecules as crystalline water, which are not coordinated [14], whereas the coordinated water molecules will be degraded at $150-200{ }^{\circ} \mathrm{C}$ [15]. Hence, the nickel complex has five water molecules as hydrates or lattice water, and it can be approximated that the formula of this complex is $\mathrm{Ni}(\mathrm{AAP})_{3}\left(\mathrm{NO}_{3}\right)_{2} \cdot 5 \mathrm{H}_{2} \mathrm{O}$. The reduction of mass continued up to $560{ }^{\circ} \mathrm{C}$, as expected for the decomposition of organic compounds. The complex was seen to achieve stability at temperatures

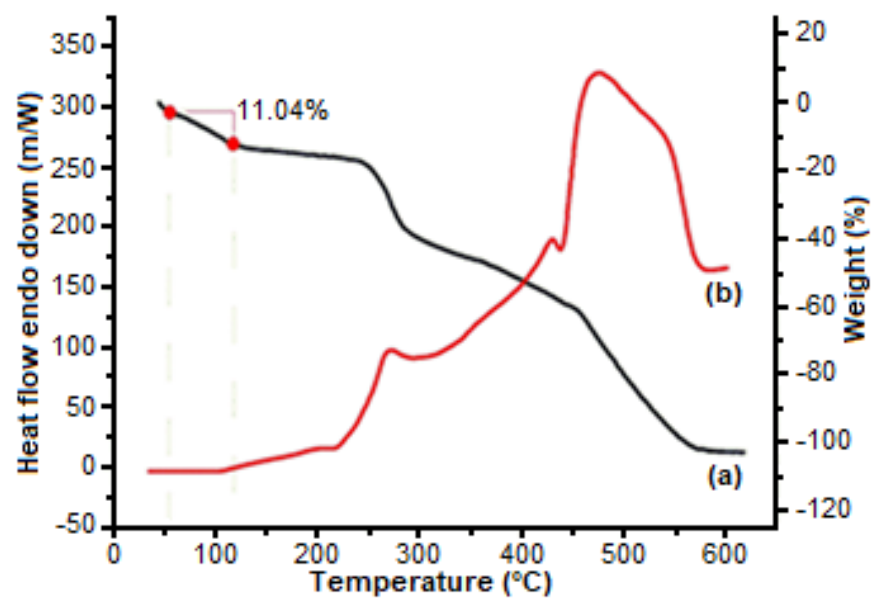

Fig 3. Thermograms of (a) TG and (b) DSC of the Ni(II)AAP complex

Table 1. Nickel content in the complex and the plausible complex formula

\begin{tabular}{ccccc}
\hline No & Empirical Formula & $\mathrm{Mr}$ & $\begin{array}{c}\text { Nickel content } \\
\text { theoretically (\%) }\end{array}$ & AAS Result (\%) \\
\hline 1 & $\mathrm{Ni}(\mathrm{AAP})_{3}\left(\mathrm{NO}_{3}\right)_{2}\left(\mathrm{H}_{2} \mathrm{O}\right)_{4}$ & 864.48 & 6.79 & \\
2 & $\mathrm{Ni}(\mathrm{AAP})_{3}\left(\mathrm{NO}_{3}\right)_{2}\left(\mathrm{H}_{2} \mathrm{O}\right)_{5}$ & 882.50 & 6.65 & 6.63 \\
3 & $\mathrm{Ni}(\mathrm{AAP})_{3}\left(\mathrm{NO}_{3}\right)_{2}\left(\mathrm{H}_{2} \mathrm{O}\right)_{6}$ & 900.51 & 6.51 & \\
\hline
\end{tabular}


higher than $550{ }^{\circ} \mathrm{C}$ due to the production of $\mathrm{NiO}$ residue (8.53\%). The amount of nickel oxide residue was found to be in accordance with the nickel content found in the complex from the AAS analysis results.

\section{Infrared Spectra Analysis}

Infrared spectra of the free ligand and $\mathrm{Ni}(\mathrm{II})$ complex (Fig. 4) were recorded to determine the functional groups of ligand that were bound to the metal ion, and their prominent infrared spectra are shown in Table 2. The complex's infrared spectrum exhibited new broadband at $3397 \mathrm{~cm}^{-1}$, which is ascribed to the $v(\mathrm{O}-\mathrm{H})$ group of lattice water [16]. Also, a new band of the nitrate group as counterions appeared at $1384 \mathrm{~cm}^{-1}$ [17]. Bands corresponding to the $v(\mathrm{~N}-\mathrm{H})$ at $3198 \mathrm{~cm}^{-1} ; 3108 \mathrm{~cm}^{-1}$ and $v(\mathrm{C}=\mathrm{O})$ at 1616 have shifted to lower wavenumbers compared to its free ligand. This result is the consequence of the shortening of bonds of $\mathrm{N}-\mathrm{H}$ and $\mathrm{C}-\mathrm{O}$. This showed that the nitrogen of amino groups and oxygen of carbonyl group in the AAP ligand was coordinated to the central ion [18-19]. This coordination was strengthened by the existence of bands at $507 \mathrm{~cm}^{-1}$ and $431 \mathrm{~cm}^{-1}$ which represented the $\mathrm{Ni}-\mathrm{O}$ and $\mathrm{Ni}-\mathrm{N}$, respectively [20].

\section{Electrical Conductivity Analysis}

The complex electrical conductivity measurement is applied to determine the position of nitrate ions, which can act as ligands or counterions, by comparing to the electrical conductivity of the standard solutions of known metal salts shown in Table 3. The result showed that the complex solution in water was an electrolyte with a molar conductance of $234 \mathrm{~S} \mathrm{~cm}^{2} \mathrm{~mol}^{-1}$. The value is also in the range of the standard solutions with a cation-anion charge ratio of $2: 1$. It signified that the nitrate ions acted as uncoordinated counterions. Thus,

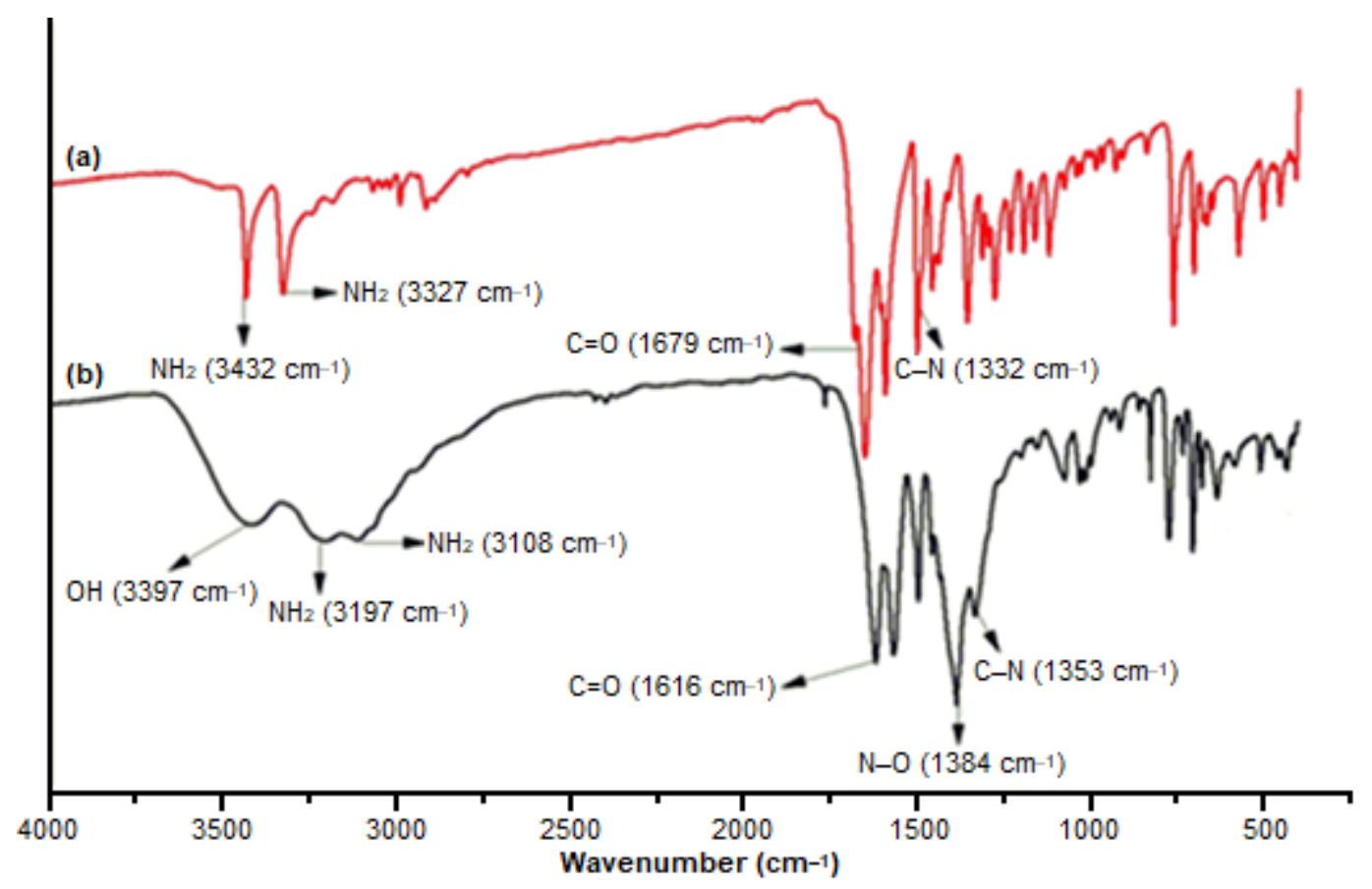

Fig 4. FTIR spectra of the (a) AAP and (b) Ni(II)-AAP complexes

Table 2. Infrared spectra absorption data of the AAP and its nickel complexes

\begin{tabular}{|c|c|c|c|c|c|c|c|}
\hline \multirow{2}{*}{ No } & \multirow{2}{*}{ Compound } & \multicolumn{6}{|c|}{ IR absorption $\left(\mathrm{cm}^{-1}\right)$} \\
\hline & & $v(\mathrm{O}-\mathrm{H})$ & $v(\mathrm{~N}-\mathrm{H})$ & $v(\mathrm{C}=\mathrm{O})$ & $v(\mathrm{~N}-\mathrm{O})$ & $v(\mathrm{Ni}-\mathrm{O})$ & $v(\mathrm{Ni}-\mathrm{N})$ \\
\hline 1 & AAP & - & $\begin{array}{l}3432_{\text {sym }} \\
3327_{\text {asym }}\end{array}$ & 1679 & - & - & - \\
\hline 2 & Ni(II)-AAP & 3397 & 3198 & 1616 & 1384 & 507 & 431 \\
\hline
\end{tabular}


Table 3. Electrical conductivity of metal salts standard and nickel(II) complex in water

\begin{tabular}{clcc}
\hline No & \multicolumn{1}{c}{ Solution } & $\Lambda_{\mathrm{m}}\left(\mathrm{S} \mathrm{cm}^{2} \mathrm{~mol}^{-1}\right)$ & Cation:anion charge \\
\hline 1 & Water & 4 & - \\
2 & $\mathrm{CuSO}_{4} \cdot 5 \mathrm{H}_{2} \mathrm{O}$ & 185 & $1: 1$ \\
3 & $\mathrm{FeSO}_{4} \cdot 6 \mathrm{H}_{2} \mathrm{O}$ & 196 & $1: 1$ \\
4 & $\mathrm{Co}\left(\mathrm{NO}_{3}\right)_{2} \cdot 6 \mathrm{H}_{2} \mathrm{O}$ & 235 & $2: 1$ \\
5 & $\mathrm{Ni}\left(\mathrm{NO}_{3}\right)_{2} \cdot 6 \mathrm{H}_{2} \mathrm{O}$ & 248 & $2: 1$ \\
6 & $\mathrm{CrCl}_{3} \cdot 6 \mathrm{H}_{2} \mathrm{O}$ & 363 & $3: 1$ \\
7 & $\mathrm{Ni}(\mathrm{II})-\mathrm{AAP}$ & 234 & $2: 1$ \\
\hline
\end{tabular}

the complex could dissociate into $\left[\mathrm{Ni}(\mathrm{AAP})_{3}\right]^{2+}$ and two $\mathrm{NO}_{3}{ }^{-}$ions in solution, and it reinforced the prediction of complex formula into [ $\left.\mathrm{Ni}\left(\mathrm{AAP}_{3}\right)\right]\left(\mathrm{NO}_{3}\right)_{2} \cdot 5 \mathrm{H}_{2} \mathrm{O}$, namely trisaminoantipyrinenickel(II) nitrate pentahydrate.

\section{Electronic Spectra}

Two spectral peaks that appeared at $646 \mathrm{~nm}$ $\left(15468 \mathrm{~cm}^{-1}\right)$ and $385\left(25940 \mathrm{~cm}^{-1}\right)$ (Fig. 2) were in accord with the transitions of ${ }^{3} \mathrm{~A}_{2 \mathrm{~g}}(\mathrm{~F}) \rightarrow{ }^{3} \mathrm{~T}_{\mathrm{gg}}(\mathrm{F})$ and ${ }^{3} \mathrm{~A}_{2 \mathrm{~g}}(\mathrm{~F}) \rightarrow$ ${ }^{3} \mathrm{~T}_{\mathrm{g}}(\mathrm{P})$, respectively, which was indicative of an octahedral geometry [21]. Additionally, the molar absorptivity range of the complex electronic spectrum in the range of $1-$ $100 \mathrm{~L} \mathrm{~mol}^{-1} \mathrm{~cm}^{-1}$ (4.4 and $45.8 \mathrm{~L} \mathrm{~mol}^{-1} \mathrm{~cm}^{-1}$ ) was characteristic of an octahedral $\mathrm{Ni}$ (II) complex [22]. Thus, it was evident that the complex formed an octahedral environment among the $\mathrm{Ni}(\mathrm{II})$ central ion.

\section{Magnetic Study}

Measurement of the magnetic moment showed the nickel magnetic property of the nickel complex, which effective magnetic moment $\left(\mu_{\text {eff }}\right)$ value was $2.93 \mathrm{BM}$. It indicated that the paramagnetic nickel complex has two unpaired electrons [23]. Meanwhile, the $\mu_{\text {eff value slightly }}$ differed compared to the spin only moment of $2.83 \mathrm{BM}$ due to the donation of orbitals in the metal ion. Other contributing influences include corrections by temperature and diamagnetic factors. The magnetic moments of octahedral complexes in the range of 2.9 to 3.4 BM [23-25] were also supported by the $\mathrm{Ni}(\mathrm{II})$-AAP complex being a six coordinated octahedral structure [26]. This value was in agreement with the electronic spectrum of the Ni(II)-AAP complex. Based on the characterization data, a complex structure with facial isomers was proposed (Fig. 5). The complex is the most

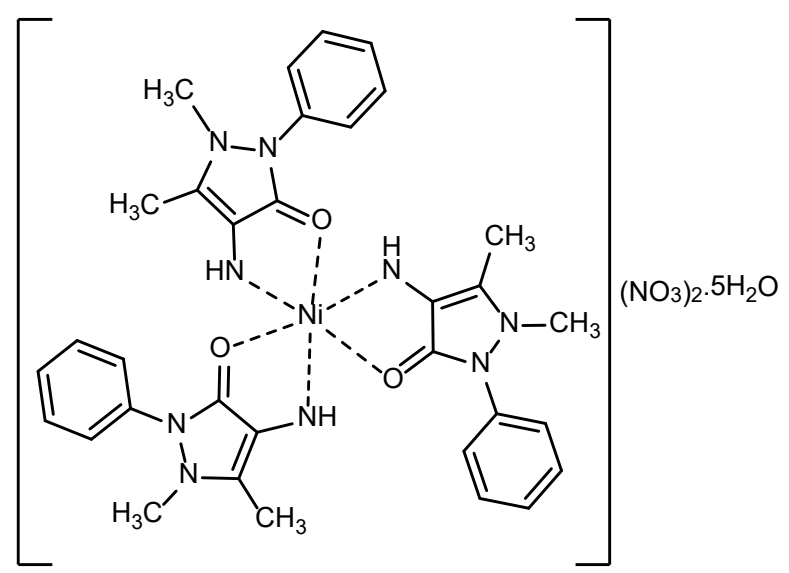

Fig 5. Suggested structure of the $\left[\mathrm{Ni}(\mathrm{AAP})_{3}\right]\left(\mathrm{NO}_{3}\right)_{2} \cdot 5 \mathrm{H}_{2} \mathrm{O}$

preferred because it has three $\mathrm{O}-\mathrm{M}-\mathrm{N}$ bonding configurations with opposite electronic characteristics when interacting with the same metal $d$ orbital. Therefore, such coordination avoided the reduction in electron delocalization and also contributed to a stronger M-ligand bond [27].

\section{Antibacterial Activity}

The antibacterial activity assays of the complex, metal salt, and the free ligand were carried out against $S$. aureus (Gram-positive bacterial) and E. coli (Gramnegative bacterial) using the agar diffusion method. The inhibition of bacterial growth is demonstrated by the formation of a clear zone around the paper disc, and results of the inhibition zone are collected in Table 4. The was shown that all compounds could inhibit the growth of both types of bacteria. The diameter of AAP and $\mathrm{Ni}\left(\mathrm{NO}_{3}\right)_{2} \cdot 6 \mathrm{H}_{2} \mathrm{O}$ inhibition zones against E. coli bacteria was smaller than that of $S$. aureus. This was due to differences in their membrane composition, in which 
Table 4. Antibacterial result of AAP, nickel salt, and its complex

\begin{tabular}{|c|c|c|c|c|}
\hline \multirow{2}{*}{ No } & \multirow{2}{*}{ Compounds } & \multirow{2}{*}{$\begin{array}{l}\text { Concentration } \\
\quad\left(\mu \mathrm{g} \mathrm{mL} L^{-1}\right)\end{array}$} & \multicolumn{2}{|c|}{ The diameter of Inhibition zone ( $\mathrm{mm}$ ) } \\
\hline & & & E. coli (G-) & S. aureus $(\mathrm{G}+)$ \\
\hline \multirow[t]{5}{*}{1} & AAP & 62.5 & 6.21 & 6.85 \\
\hline & & 125 & 6.25 & 7.01 \\
\hline & & 250 & 6.63 & 7.12 \\
\hline & & 500 & 6.73 & 7.18 \\
\hline & & 1000 & 6.93 & 7.21 \\
\hline \multirow[t]{5}{*}{2} & $\mathrm{Ni}\left(\mathrm{NO}_{3}\right)_{2} \cdot 6 \mathrm{H}_{2} \mathrm{O}$ & 62.5 & 6.71 & 7.19 \\
\hline & & 125 & 6.95 & 7.38 \\
\hline & & 250 & 7.14 & 7.57 \\
\hline & & 500 & 7.23 & 7.77 \\
\hline & & 1000 & 7.36 & 8.00 \\
\hline \multirow[t]{5}{*}{3} & {$\left[\mathrm{Ni}(\mathrm{AAP})_{3}\right]\left(\mathrm{NO}_{3}\right)_{2} \cdot 5 \mathrm{H}_{2} \mathrm{O}$} & 62.5 & 8.59 & 8.13 \\
\hline & & 125 & 8.70 & 8.22 \\
\hline & & 250 & 8.78 & 8.33 \\
\hline & & 500 & 8.89 & 8.88 \\
\hline & & 1000 & 8.96 & 8.95 \\
\hline 4 & DMSO & 0 & 0 & 0 \\
\hline 5 & Chloramphenicol & 30 & 27.12 & 28.74 \\
\hline
\end{tabular}

E. coli has a more complex cell membrane structure [2829]. However, this was not the case for the complex, which has a smaller inhibition zone difference between both bacteria. Their antibacterial activity was found to increase with increasing concentration [4], but the complex exhibited a higher inhibitory activity than the metal and free ligand, as shown in the following order: nickel complex $>$ nickel salt $>$ AAP.

Duncan Multiple Range Test (DMRT) was performed on the inhibitory diameters of all compounds against both bacteria at varying concentrations of $62.5 ; 125 ; 250 ; 500$ and $1000 \mu \mathrm{g} / \mathrm{mL}$. Each compound showed significance values of $\mathrm{p}<0.05$, in which the mean results were significantly different from each other for the inhibition of bacterial growth by the nickel complex, nickel salt, and AAP ligand. In addition, it also showed a significant increase in the antibacterial activity when $\mathrm{Ni}$ (II) and AAP were complexed into $\left[\mathrm{Ni}(\mathrm{AAP})_{3}\right]\left(\mathrm{NO}_{3}\right)_{2} \cdot 5 \mathrm{H}_{2} \mathrm{O}$.

The nickel complex exhibited the highest antibacterial activity due to complexation with AAP. Results of the inhibitory tests showed that the metal and ligand worked in synergy after complexing. AAP is a bidentate ligand chelated with the metal ion and deactivated various enzyme cells which roles are important in bacterial metabolism [30]. The chelation effect can be described by Tweedy's chelation theory that explains the chelate can reduce nickel polarity [31]. This, consequently, increases the lipophilic character of the metal ion, which facilitates the penetration of the complex through the lipid membrane [32]. Thus, the complex can disrupt the synthesis or other biological processes in bacteria, for instance, deactivating enzymes and also breaking down bacterial cells [33] and ultimately inhibit bacterial growth.

\section{- CONCLUSION}

In this work, the nickel(II) complex, $\left[\mathrm{Ni}(\mathrm{AAP})_{3}\right]\left(\mathrm{NO}_{3}\right)_{2} \cdot 5 \mathrm{H}_{2} \mathrm{O}$, namely trisaminoantipyrine nickel(II) nitrate pentahydrate, was synthesized and characterized. The ligand to metal ion binding mode was confirmed by IR studies, also supported by TG/DSC and electrical conductivity studies. AAP was coordinated to nickel ion through carbonyl oxygen and amino nitrogen. The octahedral geometry of the Ni(II)-AAP complex was corroborated by electronic spectra and magnetic studies, in which the complex was paramagnetic and displayed electrolyte property. The complex exhibited the highest inhibitory zones due to the chelating effect. 
The coordination of AAP with nickel(II) seems to be promising to increase the antibacterial activity.

\section{- ACKNOWLEDGMENTS}

The authors would like to acknowledge the Sebelas Maret University for financial support through the Hibah Penelitian Fundamental PNBPUNS.

\section{- AUTHOR CONTRIBUTIONS}

YAR, MKW, SDM, and SBR conceived and planned the experiment. YAR and MKW contributed to sample preparation and conducted the experiment. YAR, SDM, and SBR contributed to the interpretation of the results. YAR and SBR took the lead in writing the manuscript. All authors agreed to the final version of this manuscript.

\section{- REFERENCES}

[1] Poormohammadi, E.B., Behzad, M., Abbasi, Z., and Astaneh, S.D.A., 2020, Copper complexes of pyrazolone-based Schiff base ligands: Synthesis, crystal structures and antibacterial properties, J. Mol. Struct., 1205, 127603.

[2] Selvi, E.T., and Mahalakshmi, S., 2017, Synthesis and characterisation of a new heterocyclic Schiff base ligand derived from 4-aminoantipyrine, Int. J. $A d v$. Res. Dev., 2 (2), 51-56.

[3] Singh, G., Satija, P., Singh, B., Sinha, S., Sehgal, R., and Sahoo, S.C., 2020, Design, crystal structures and sustainable synthesis of family of antipyrine derivatives: Abolish to bacterial and parasitic infection, J. Mol. Struct., 1199, 127010.

[4] Masruri, M., Amini, R.W., and Rahman, M.F., 2016, Potassium permanganate-catalyzed alpha-pinene oxidation: Formation of coordination compound with zinc(II) and copper(II), and growth inhibition activity on Staphylococcus aureus and Escherichia coli, Indones. J. Chem., 16 (1), 59-64.

[5] Sageer, A.G., Saheeb, A.A., and Mekky, A.H., 2020, Microwave synthesis, characterization of some novel curcumin compound and its metal complexes with antimicrobial, antioxidant studies, Int. J. Pharm. Res., 12 (1), 1092-1103.

[6] Teran, R., Guevara, R., Mora, J., Dobronski, L.,
Barreiro-Costa, O., Beske, T., Pérez-Barrera, J., Araya-Maturana, R., Rojas-Silva, P., Poveda, A., and Heredia-Moya, J., 2019, Characterization of antimicrobial, antioxidant, and leishmanicidal activities of Schiff base derivatives of 4aminoantipyrine, Molecules, 24 (15), 2696.

[7] Kumar, K.V., Sunand, K., Ashwini, K., Kumar, P.S., Vishnu, S., and Samala, A., 2017, Synthesis characterization and antibacterial studies of 4aminoantipyrine Schiff s bases, Int. J. Appl. Pharm. Sci. Res., 2 (1), 8-14.

[8] Mohammed, L.A., Mehdi, R.T., and Ali, A.A.M., 2018, Synthesis and biological screening of the gold complex as anticancer and some transition metal complexes with new heterocyclic ligand derived from 4-aminoantipyrine, Nano Biomed. Eng., 10 (3), 199-212.

[9] Singh, M.K., Roy, S., Hansda, A., Kumar, S., Kumar, M., Kumar, V., Peter, S.C., and John, R.P., 2017, Synthesis, characterization and antibacterial activity evaluation of trinuclear $\mathrm{Ni}(\mathrm{II})$ complexes with N-substituted salicylhydrazide ligands, Polyhedron, 126, 100-110.

[10] Jayalakshmi, R., Priya, D.D., Jayakkumar, V., and Rajavel, R., 2017, Synthesis and characterization of 4-aminoantipyrine based Schiff base complexes: antimicrobial, cytotoxicity and DNA cleavage studies, Int. J. Eng. Res. Technol., 6 (8), 1-9.

[11] Soltani, S., Akhbari, K., and White, J., 2020, Synthesis, crystal structure and antibacterial activity of a homonuclear nickel(II) metal-organic nanosupramolecular architecture, Polyhedron, 176, 114301.

[12] Sarker, D., Hossen, M.F., Kudrat-E-Zahan, M., Haque, M.M., Zamir, R., and Asraf, M.A., 2020, Synthesis, characterization, thermal analysis and antibacterial activity of $\mathrm{Cu}$ (II) and $\mathrm{Ni}$ (II) complexes with thiosemicarbazone derived from thiophene-2aldehyde, J. Mater. Sci. Res. Rev., 5 (2), 15-25.

[13] Syaima, H., Rahardjo, S.B., and Zein, I.M., 2018, Synthesis and characterization of diranitidinecopper(II) sulfatedehydrate, IOP Conf. Ser.: Mater. Sci. Eng., 349 (1), 012025. 
[14] Wang, X., Gao, C.Q., Gao, Z.Y., Wu, B.L., and Niu, Y.Y., 2018, Synthesis, crystallographic and spectral studies of homochiral cobalt(II) and nickel(II) complexes of a new terpyridylaminoacid ligand, $J$. Mol. Struct., 1157, 395-363.

[15] Anupama, B., Sunita, M., Shiva Leela, D., Ushaiah, B., and Gyana Kumari, C., 2014, Synthesis, spectral characterization, DNA binding studies and antimicrobial activity of $\mathrm{Co}(\mathrm{II}), \mathrm{Ni}(\mathrm{II}), \mathrm{Zn}(\mathrm{II}), \mathrm{Fe}(\mathrm{III})$ and $\mathrm{VO}$ (IV) complexes with 4-aminoantipyrine Schiff base of ortho-vanillin, J. Fluoresc., 24 (4), 1067-1076.

[16] Sinthuja, S.A., Shaji, Y.C., and Rose, G.L., 2018, Synthesis, characterization and evaluation of biological properties of transition metal chelates with Schiff base ligands derived from glutaraldehyde with L-leucine, Int. J. Sci. Res. Sci. Technol., 4 (2), 587-593.

[17] Tyagi, M., Chandra, S., Tyagi, P., Akhtar, J., Kandan, A., and Singh, B., 2017, Synthesis, characterization and anti-fungal evaluation of $\mathrm{Ni}(\mathrm{II})$ and $\mathrm{Cu}(\mathrm{II})$ complexes with a derivative of 4-aminoantipyrine, J. Taibah Univ. Sci., 11 (1), 110-120.

[18] de Souza, Í.P., Machado, B.P., de Carvalho, A.B., Binatti, I., Krambrock, K., Molphy, Z., Kellett, A., Pereira-Maia, E.C., and Silva-Caldeira, P.P., 2019, Exploring the DNA binding, oxidative cleavage, and cytotoxic properties of new ternary copper(II) compounds containing 4-aminoantipyrine and $\mathrm{N}$, N-heterocyclic co-ligands, J. Mol. Struct., 1178, 18-28.

[19] Venugopal, N., Krishnamurthy, G., Bhojyanaik, H.S., and Krishna, P.M., 2019, Synthesis, spectral characterization and biological studies of $\mathrm{Cu}(\mathrm{II})$, $\mathrm{Co}(\mathrm{II})$ and $\mathrm{Ni}(\mathrm{II})$ complexes of azo dye ligand containing 4-aminoantipyrine moiety, J. Mol. Struct., $1183,37-51$.

[20] Fathima, S.S.A., Paulpandiyan, R., and Nagarajan, E.R., 2019, Expatiating biological excellence of aminoantipyrine derived novel metal complexes: Combined DNA interaction, antimicrobial, free radical scavenging studies and molecular docking simulations, J. Mol. Struct., 1178, 179-191.

[21] Rahardjo, S.B., and Aditya, H.P., 2017, Synthesis and characterization of tetrakis(2-amino-3-methyl
pyridine)di(aqua)nickel(II), IOP Conf. Ser.: Mater. Sci. Eng., 172, 012048.

[22] Cotton, F.A., Wilkinson, G., Murillo, C.A., and Bochmann, M., 1999, Advanced Inorganic Chemistry, John Willey \& Sons Inc., New York.

[23] Kumari, P., Lobana, T.S., Butcher, R.J., Castineiras, A., and Zeller, M., 2018, The effect of substituents at $\mathrm{C}^{2} / \mathrm{N}^{1}$ atoms of salicyladehyde and 2hydroxyacetophenone based thiosemicarbazones on the nature of nickel(II) complexes with 1,10phenathroline and terpyridine as co-ligands, Inorg. Chim. Acta, 482, 268-274.

[24] Sharma, S., Sachar, R., Bajju, G.D., and Sharma, V., 2018, Synthesis and characterization of some adducts of o-hexyl dithiocarbonates of nickel (II) with heterocyclic amines, Chem. Sci. Trans., 7 (4), 610-617.

[25] Baul, T.S.B., Nongsiej, K., Ka-Ot, A.L., Joshi, S.R., Rocha, B.G.M., and da Silva, M.F.C.G., 2020, Synthesis, crystal structures, magnetic properties and antimicrobial screening of octahedral nickel(II) complexes with substituted quinolin-8-olates and pyridine ligands, J. Mol. Struct., 1200, 127106.

[26] Rasyda, Y.A., Rahardjo, S.B., and Nurdiyah, F., 2019, Synthesis and characterization complex nickel(II) with diphenylamine, IOP Conf. Ser.: Mater. Sci. Eng., 578, 012008.

[27] Lima, C.F.R.A.C, Taveira, R.J.S., Costa, J.C.S., Fernandes, A.M., Melo, A., Silva, A.M.S., and Santos, L.M.N.B.F., 2016, Understanding M-ligand bonding and mer-/fac-isomerism in tris(8hydroxyquinolinate) metallic complexes, Phys. Chem. Chem. Phys., 18 (24), 16555-16565.

[28] Susanthy, D., Santosa, S.J., and Kunarti, E.S., 2020, Antibacterial activity of silver nanoparticles capped by $p$-aminobenzoic acid on Escherichia coli and Staphylococcus aureus, Indones. J. Chem., 20 (1), 182-189.

[29] Pratama, A., Sebayang, F., and Nasution, R.B., 2018, Antibacterial properties of biofilm Schiff base derived from dialdehyde cellulose and chitosan, Indones. J. Chem., 19 (2), 405-412. 
[30] Shebl, M., 2016, Mononuclear, homo- and heterobinuclear complexes of 1-(5-(1-(2-aminophenylimi no)ethyl)-2,4-dihydroxyphenyl)ethanone: Synthesis, magnetic, spectral, antimicrobial, antioxidant, and antitumor, J. Coord. Chem., 69 (2), 199-214.

[31] Nithya, P., Rajamanikandan, R., Simpson, J., Ilanchelian, M., and Govindarajan, S., 2018, Solvent assisted synthesis, structural characterization and biological evaluation of cobalt(II) and nickel(II) complexes of Schiff bases generated from benzyl carbazate and cyclic ketones studies, Polyhedron, 145, 200-217.

[32] Malik, S., Das, S., and Jain, B., 2010, First-row transition metal complexes of omeprazole as antiulcerative drugs, Indones. J. Chem., 10 (3), 382-389.

[33] Doan, V.D., Cuong, N.V., Le, P.H.A., Anh, T.T.L., Viet, P.T., and Huong, N.T.L., 2020, Orange peel essential oil nanoemulsions supported by nanosilver for antibacterial application, Indones. J. Chem., 20 (2), 430-439. 